\title{
White Marble, Black Bodies and the Fear of the Invisible Negro: Signifying Blackness in Mid-Nineteenth-Century Neoclassical Sculpture
}

\author{
Charmaine A. Nelson
}

Volume 27, numéro 1-2, 2000

URI : https://id.erudit.org/iderudit/1069725ar

DOI : https://doi.org/10.7202/1069725ar

\section{Aller au sommaire du numéro}

\section{Éditeur(s)}

UAAC-AAUC (University Art Association of Canada | Association d'art des universités du Canada)

\section{ISSN}

0315-9906 (imprimé)

1918-4778 (numérique)

Découvrir la revue

Citer cet article

Nelson, C. A. (2000). White Marble, Black Bodies and the Fear of the Invisible Negro: Signifying Blackness in Mid-Nineteenth-Century Neoclassical Sculpture. RACAR : Revue d'art canadienne / Canadian Art Review, 27(1-2), 87-101. https://doi.org/10.7202/1069725ar

\section{Résumé de l'article}

La sculpture néoclassique du XIXe siècle a été profondément marquée par les différences raciales inscrite dans le corps. L'esclavage transatlantique, l'abolitionnisme et la Reconstruction fournirent aux artistes de nouveaux thèmes socialement complexes qui s'accommodèrent facilement du sujet noir féminin. Pourtant, celui-ci faisaient problème pour le néoclassicisme (et le " grand » art en général) puisqu'il était doublement éloigné des idéaux de la couleur blanche et de la masculinité. Cet article examine de quelle façon le sujet noir féminin s’avère une (im)possibilité autant au niveau esthétique, narratif que thématique. De manière significative, la dépendance esthétique du néoclassicisme pour la marbre blanc refusait l'expression raciale au niveau même de la peau. Ce phénomène attire l'attention sur les nombreuses angoisses sociales de l'époque pour les contacts et les croisements entre les races qui permirent la prédominance d'un type féminin noir-blanc. Puisque la pratique néoclassique faisait inextricablement partie des discours raciaux du XIXe siècle, les historiens n'ont pas su reconnaître l'importance de la race dans ce type de production et dans la culture visuelle en général. Dans cet article, nous tenterons " d'excaver » les contextes coloniaux originaux de production et d'en analyser les implications pour les artistes, les sujets et la culture visuelle.
Tous droits réservés (c) UAAC-AAUC (University Art Association of Canada | Association d'art des universités du Canada), 2003
Ce document est protégé par la loi sur le droit d'auteur. L'utilisation des services d'Érudit (y compris la reproduction) est assujettie à sa politique d'utilisation que vous pouvez consulter en ligne.

https://apropos.erudit.org/fr/usagers/politique-dutilisation/ 


\title{
White Marble, Black Bodies and the Fear of the Invisible Negro: Signifying Blackness in Mid-Nineteenth-Century Neoclassical Sculpture
}

\author{
Charmaine A. Neison, MCGill University
}

\section{Résumé}

La sculpture néoclassique du XIXe siècle a été profondément marquée par les différences raciales inscrite dans le corps. L'esclavage transatlantique, l'abolitionnisme et la Reconstruction fournirent aux artistes de nouveaux thèmes socialement complexes qui s'accommodèrent facilement du sujet noir féminin. Pourtant, celui-ci faisaient problème pour le néoclassicisme (et le «grand»art en général) puisqu'il était doublement éloigné des idéaux de la couleur blanche et de la masculinité. Cet article examine de quelle façon le sujet noir féminin s'avère une (im)possibilité autant au niveau esthétique, narratif que thématique. De manière significative, la dépendance esthétique du néoclassicisme pour la marbre blanc refusait l'expression raciale au niveau même de la peau. Ce phenomène attire l'attention sur les nombreuses angoisses sociales de l'époque pour les contacts et les croisements entre les races qui permirent la prédominance d'un type féminin noir-blanc. Puisque la pratique néoclassique faisait inextricablement partie des discours raciaux du XIXe siècle, les historiens n'ont pas su reconnaître l'importance de la race dans ce type de production et dans la culture visuelle en général. Dans cet article, nous tenterons « d'excaver » les contextes coloniaux originaux de production et d'en analyser les implications pour les artistes, les sujets et la culture visuelle.
$\mathrm{W}_{\text {it }}$

There was certainly a discernable preoccupation with chains, shackles, and slaves which found expression in American sculpture ... In any case this concern with chains amounted to almost a national mania. ${ }^{1}$

Although uncritical and devoid of context, what Gardner had aptly recognized was the significance and indeed centrality of the slave as a subject of representation within the thematic and narrative possibilities of an art form contextualized by coloniality: trans-Atlantic Slavery, the American Civil War and American Reconstruction. The and in Gardner's "chains, shackles and slaves" is, however, slightly misleading since it connotes three distinct categories. Rather, the preoccupation he described was with the shackling and chaining of the slave body - a slave body which was partially legible due to the very same implements of torture and restraint. Shackles and chains were readily identifiable as the social and symbolic markers of the slave subject and as such did not merely represent the physical restraint, containment and oppression of the commodified body, but were themselves legible signs of a slave status and a part of the process of commodification. In citing the slave body as a popular subject of representation, Gardner was locating race as a critical term of identification within the colonial west of the nineteenth century. ${ }^{2}$ Yet, while Gardner left the slave body unsexed, I would argue that the slave subjects with whom nineteenth-century neoclassicists were most preoccupied were female.

Within the colonial logic of the nineteenth century exemplified by trans-Atlantic Slavery, race was a critical and unavoid- able term of identification. The discursive and material practices of the "peculiar institution" reveal the signification of blackness as an inextricable component of the identification of the slave body. ${ }^{3}$ In my examination of black female subjectivity, I am seeking to retrieve the specificity of racial identifications and their inseparability from the signification of sex/gender within the context of nineteenth-century neoclassical sculpture. In so doing I am interrogating the material and aesthetic processes by which race is represented within visual culture and the symbolic positions to which racialized bodies were assigned. The material and aesthetic specificity which I will consider is neoclassicism's essential deference to white marble and the representational and narrative limits of the black female subject within the colonial practice of nineteenth-century visual culture in the west. When a sculptural medium is fundamentally white, how is blackness signified within a colonial visual register historically reliant upon the legibility of skin colour? And what was the purpose and funcrion of this aesthetic disavowal, the suppression of black skin and inevitably the black body?

The idea of becoming describes the process of the body's materializations and identifications which are unstable and unfixed. Becoming as a concept that indicates a transformation necessarily implicates time which has the power of invisibility while simultaneously rendering that which it encompasses visible. ${ }^{4}$ Judith Butler has argued that "... identifications are never simply or definitely made or achieved; they are constituted, contested, and negotiated." 5 Rather than a theory of the body which locates an a priori identity, I am defining representation as the very ground in which identities are fabricated and made possible, the place where identity occurs and the subject becomes. The cultural term of representation is not merely a means 
of reproducing in visual language a body which is always already locked into a particular network of identifications. Rather, representation is a visual process which must be confronted as part of the body's materialization, a cultural field wherein the process of differentiation takes place, signification occurs and symbolic identifications are assigned and maintained. The visual processes of representing the body are acts of differentiation which delineate the surfaces and boundaries of the body through acts of selective inclusion and exclusion. Often ambivalent, they create hegemonic identifications within dialectical relationships. Butler again guides me in her questioning: "What is excluded from the body for the body's boundary to form? And how does that exclusion haunt that boundary as an internal ghost of sorts ... To what extent is the body surface the dissimulated effect of loss?" It is these moments of ambivalence, when the represented body cannot be fully reconciled with its assigned symbolic position, that the political, social and cultural investments of identity are revealed. My project is the location of these absences and ghosts, or what Stuart Hall has called "what is left outside", following the traces of what is disavowed and what is strenuously affirmed. ' It is the excavation of these sites of rupture or slippage, caused by ceaseless movement and negotiations, wherein such conflations cannot sustain themselves but reveal their discursivity and the structures of their materialization. ${ }^{8}$

The significance of a discussion of the politics of racial identification within nineteenth-century neoclassical sculpture must be understood in terms of an overwhelming narrative intention which Joy Kasson has defined as "art for morality's sake". " But it must also be reconciled with the prolific influence of scientific racism. The material and aesthetic processes of sculpture and its investment in the notion of the ideal body were inherently well suited to the colonial practices of the human sciences, providing representational validation (in threedimensional solidity) of stereotypes of racial difference. ${ }^{10}$ The nineteenth century's scylistic dependence upon classical sculpture, broadly termed neoclassicism, located the privileging of the white body as the aesthetic paradigm of beauty. Quite simply, the term classical was not neutral, but a racialized term which activated the marginalization of blackness as its antithesis.

The currency of abolitionist and pro-slavery discourses within nineteenth-century popular culture contributed to the growing visibility of the black female subject. However, the parallel inclusion of the black subject into the exclusive canon of western sculpture was not, in itself, democratizing. I contend that the specificities of aesthetic and material practice, as well as thematic, narrative, compositional and expressive choices allowed for the continual deployment of an abject black subject. In short, not just the field of sculpture, but the practice of western art generally was colonial - this shift in the visibility of the black female subject could not, of itself, constitute a change in ideology.

I wish to explore the racial identifications of the black female subject within nineteenth-century neoclassical sculpture informed by the specificity of material and aesthetic practices which disavowed racial difference through the privileging of whiteness. Within a nineteenth-century colonial order which privileged a white male viewing and producing body, white racial anxiety over the potential contact with the "other" body of the black subject - an anxiety which was visualized within sculptures which refused to signify blackness - recalled instead a miscegenated, white-negro body which both alleviated and embodied the fears of inter-racial contact.

Neoclassical sculpture is often readily identifiable not only for its obvious appropriation of a classical visual vocabulary, but also for its adherence to the stark whiteness of its marble medium. Therefore, with neoclassical sculpture, we must contend with a style which is not only identifiable through a distinct visual language, but is also due to a decided preference for a certain type and colour of material. This is not merely a case of the refusal of colour but the deliberate preference and validation of whiteness as the aesthetic choice which would result in a desired symbolic result, which had everything to do with contemporary racialized ideals of beauty and the body. Noting the neoclassical preference for white marble, Edward E. Hale contemplated the logic behind this aesthetic choice and its alternatives:

The real question, then, is this: If next week, in some new quarry at Seravezza or in Rutland, a vein of marble more flesh-like in color should be found than any used to-day, would not every artist gladly use it in his busts of living men and women? If not, why do we not work in black marble or green? We work in white, bccause that is the nearest approach we have to the color of the human flesh ..."1

It is critical to note that Hale used "human flesh" interchangeably with white flesh, effectively disavowing racial difference and a spectrum of skin-colour possibilities. When human flesh is white flesh, is not a pinkish or yellowish hued marble naturally more desirable? Not necessarily. The answer to Hale's question was not as straightforward as one might have assumed. Frankly, it was not at all obvious to the neoclassical sculptor that a more "flesh-tinged" marble would have been preferable to their canonical stark white medium. And further, Hale's comments demonstrated his ignorance of polychromy, the contemporaneous material practice which employed the green and black marble he assumed useless.

Unlike other forms of sculpture or types of art, the medium of white marble was itself inherent to the practice of nineteenth- 
century neoclassical sculpture. The deliberate whiteness of the marble medium was nor of arbitrary significance. Rather, it functioned to mediate the representation of the racialized body in ways which preserved a moral imperative. During the midnineteenth century, notable neoclassical sculptors, their patrons and critics openly rejected the aesthetic possibilities of applied and material polychromy as an overly sensual and decorative distraction which detracted from the "true" intention and purpose of sculpture - purity and form. As I will discuss in further detail below, neoclassicists were particularly wary of polychromy's usefulness for female subjects and its efficacy for representing skin, which, alive and fleshly instead of abstracted and white, was often cited for its supposed provocation of inappropriate visceral and sexual reactions from male viewers.

The exclusivity of marble indexed the desire to reclaim the ancient aesthetic forms and materials of the Greeks and it also located the deliberate appropriation of ancient knowledge and culture which were mapped onto modern nations seeking to manifest political and cultural cohesion. Marble's symbolic value incorporated material and commercial attributes yet superceded any mere monetary value which could be assigned to the stone. Rather, the symbolic imperative of marble was also sexual and racial. White marble guarded against the threat of flesh, and flesh must be recognized not only as sexual, or sexualized, but as the locus of colour/complexion and a fundamental means of racial identification. White marble held a distinct regulatory function. In psychoanalytical terms, marble was not incidental but critical to the process of representation since it facilitated the fetishization of the body, re-presenting it in a moral guise legible as art. But as Parveen Adams has stated, fetishization is not merely a regulation of the body, it is the regulation of difference. ${ }^{12}$

Although the knowledge was suppressed by Winckelmann and rejected by other eighteenth-century scholars, nineteenthcentury neoclassical sculptors were certainly aware that the marble prototypes of their ancient predecessors had once been suffused with coloured pigment. ${ }^{13}$ Therefore, their rigid deployment of marble, which was almost exclusively faithful to the original whiteness of the medium, located a conscious ideological choice. ${ }^{14}$ Neoclassical anxiety about colour is evident in documentation about applied and material polychromy. ${ }^{15}$ I shall discuss both below.

Writing from Rome in December 1868, Anne Brewster commented on neoclassicism's restrictions upon the pigmentation of marble:

Painted statues are repulsive to the modern eye and taste. Gibson's tinted one in the Philadelphia Academy is a ghastly thing, and it seems impossible for us moderns to accept this practice of the ancients. ${ }^{16}$
The ghastly thing to which Brewster referred (fig. 1) was John Gibson's Tinted Venus (ca. 1851-56) which was exhibited at the International Exhibition at London (1862) and again at the Crystal Palace at Sydenham (1862) in a coloured pavilion designed by the architect Owen Jones. ${ }^{17}$ Gibson's subtle tinting of his marble Venus, achieved through the combination of hot wax and paint, recalled the flesh-colour of the white body, enacting a sexualization in its palpable shift towards a "real" female body which disturbed many viewers. ${ }^{18}$ An anonymous critic writing in The Art Journal (1862) commented, "This attempt at too palpable flesh not only destroys the very essence of the sculptor's art, but violates the delicacy that attaches to pure material." 19 Similarly, after viewing Gibson's nude in his studio, the American tourist Samuel Young Jr. commented matter-offactly, "Coloring has been used on and about the Venus, which is a blemish." ${ }^{20}$ The neoclassical desire for whiteness became a method for purging sensualism (associated with all other colours) from the marble and assuring a morally sound object - the representation of the nude as opposed to the naked body. ${ }^{21}$ But it was also a means of achieving a level of abstraction of form which denied the specificity of biological or social detail.

Although Gibson's Tinted Venus was problematic for many nineteenth-century viewers, he did receive some support. Writing in 1861, Edward E. Hale provided, although hesitantly, an alternative viewpoint when he described Gibson's tinting of marble as a process which achieved "a glow as from a warm sunset ... making the marble seem warm instead of cold." ${ }^{22} \mathrm{He}$ further explained the difference in sensorial experience in the face of the uncoloured and the tinted marble:

\footnotetext{
You have seen "Venus" in plaster: you sce her now in marble, uncolored. The figure is exquisite, and you think you are satisfied; when a curtain is drawn, and you see her sister, alive and not dead, triumphant with her gold apple, instead of shivering in affected triumph; because she is ruddy and warm and not cold and blue. ${ }^{23}$
}

Significantly, the term "ruddy" was often deployed in the nineteenth century to describe the complexion of inter-racial bodies (the children of black and white sexual unions), a point to which I will return below. In Hale's observation, the ruddiness of the marble provided the representation of skin-colour and the illusion of life which he saw as the triumph not the shame of the sculptural representation.

In his Art-Hints (1855), ${ }^{24}$ the American art critic James Jackson Jarves wrote explicitly about the use of colour in nude sculpture:

Much doubt exists as to the propriety of rendering the nude figure ... its chief claim is upon the intellect; add color, 
Figure I. John Gibson, Tinted Venus, ta. 185I-56. Marble, height $175 \mathrm{~cm}$. Liverpool, Walker Art Gallery (Photo: The Board of Trustees of the National Museums and Galleries on Merseyside, Walker Art Gallery, Liverpool, U.K.).

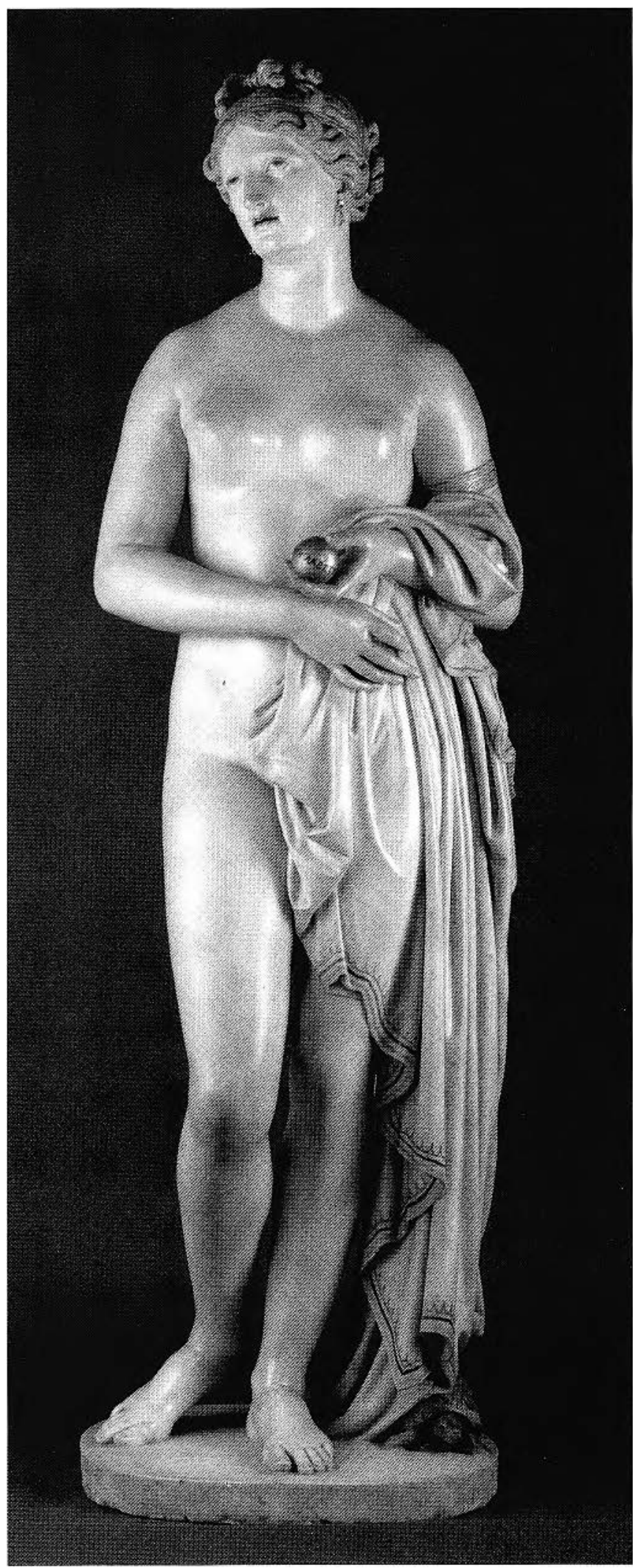

however, and upon the universal principle of nature in its use, feeling is at once touched ... A gilt or a bronze statue arouses no emotion beyond intellectual admiration; any artificial employment of color such as tinting marble, strikes the mind disagreeably as falsification of the material without any adequate motive ... I believe for sculpture itself, as confined to the human figure, that the intellectual pleasure diminishes in the degree that pure white is departed from as its material. Does any one find other pleasure in the artistic freaks of the classical ages, and the imitations of the Renaissance in the shape of blackamoors, draperies, and occasionally separate features, rendered by the natural colors of their stone-material, than in the ingenuity of these combinations? 25

Jarves' statement is worth dissection. First and again whiteness is not accorded the value of a colour but is situated as a universal category - the absence of colour. While Edward Hale had assumed that the neoclassical dominance of white marble was a matter of material availability rather than ideological choice, Jarves' championing of neoclassical whiteness was not based upon similar misinformation. Jarves' knowledge of material polychromy was likely gained through contemporaneous works like the French sculptor Charles-Henri-Joseph Cordier's Nègre du Soudan ou Nègre en costume algérien (1856-57, fig. 2). ${ }^{26}$ Also perfectly aware of the classical and Renaissance traditions of polychromy which he labelled "artistic freaks", Jarves' use of the term "blackamoors" at once registered and marginalized the expanded possibilities for racial signification which polychromy provided. In the end, his insistence upon the whiteness of marble in sculptural practice is also a Eurocentric insistence upon the universality of the white body as the aesthetic paradigm of beauty.

Just as the privileged signifier of the phallus is not the penis and is therefore irrevocably bound to the penis, whiteness, the privileged signifier of race/colour is not wholly interchangeable with white skin but is dependent upon and bound to the racialization of whiteness. The whiteness of the marble, as deployed within nineteenth-century neoclassical canons, did not directly represent Caucasian skin colour but stood in for that which could not be signified, the too palpable flesh of Gibson's Venus. But in as much as it signified that which it displaced, flesh, it privileged the European race/colour as the source of the signification and disavowed the possibility of "other" race/colour significations at the level of skin. As the Freudian concept of castration masks the reality of sexual difference, so too did the symbolic privilege of neoclassical whiteness mask the possibility of racial difference. ${ }^{27}$ Gibson's illusion of flesh had dislodged the strident whiteness of the marble and toppled its disavowal of racial difference, for in producing the effect of the white 
Figure 2. Charles-Henri-Joseph Cordier, Nègre du Soudan ou Negre en costume algérien, 1856-57. Marble, onyx, bronze, $76 \times 66 \times 36 \mathrm{~cm}$. Paris, Musée d'Orsay (Photo: Réunion des Musées Nationaux, Paris).

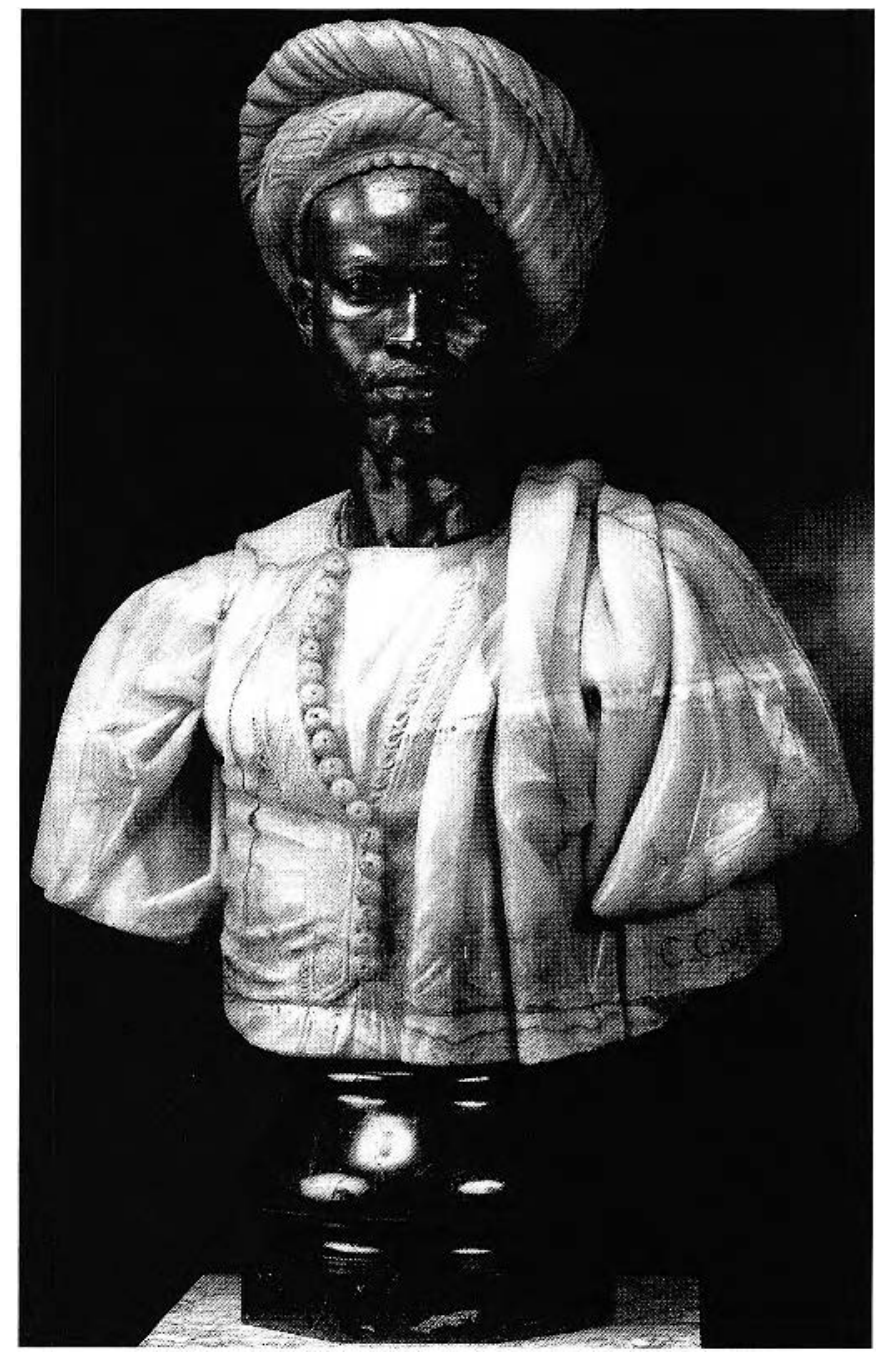

body/skin, the "other" body/skin of the black subject was also possible.

Neoclassicism's loyalty to white marble undoubtedly registered the colonial disavowal of racial difference, which points up critical tensions around the persistence of American slavery in the face of international abolitionist activism and the socalled problem of miscegenation. But racial disavowal was also performed at the level of subject and narrative. The American Hiram Powers' tremendously successful Greek Slave (1869) indexed the prolific disavowal of the bodies of black female slaves (fig. 3). Between the summer of 1842 and the fall of 1869 , Hiram Powers completed at least six known versions of the sculpture entitled Greek Slave. ${ }^{28}$ Inverting the racial identifications of colonizer/colonized, slave/master, the success of Powers' sculpture hinged upon the narration of a chaste white female sexuality under imminent threat of violation by a black (Arab)
Figure 3. Hiram Powers, Greek Slave, 1869. Marble, $167.6 \times 50.2 \times 46.7 \mathrm{~cm}$. Brooklyn, Brooklyn Museum of Art, Gift of Charles F. Bound (Photo: Brooklyn Museum of Art, Brooklyn, N.Y.).

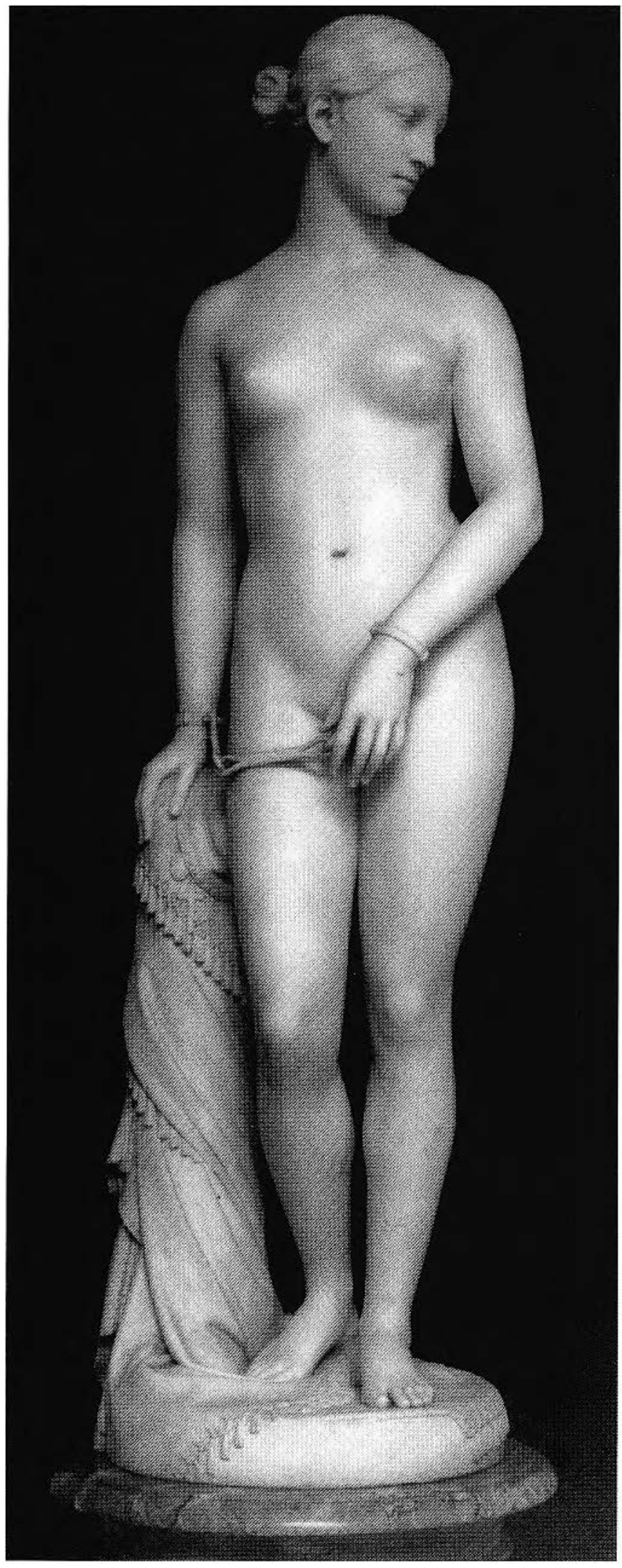


sexuality. ${ }^{29}$ Although Powers' sculpture was co-opted by abolitionists as a clear anti-slavery statement, in choosing to represent a Greek woman enslaved by the Turkish during the Greek War of Independence (1821-1830), Powers effectively disavowed the specificity and immediacy of American slavery and the black female slaves on which it depended. ${ }^{30}$

When talk of the Greek Slave's relevance to American slavery occurred, only rarely was the black female slave cited. Rather, abolitionist sympathy generally actualized around concern for the octoroon female slave. An article in the Christian Inquirer was explicit:

\footnotetext{
Let no one keep down the natural promptings of his indignation by the notion of woolly heads and black skins. Let him rather read the advertisements of these sales ... Let him not shut his eyes and his heart to the fact, that many who meet this fatc are the daughters of white men, daughters brought up in luxury, and taught to expect fortune. Let him not ignore the fact that white skins, fair hair, delicate bcauty, often enhance the market value of his country women thus exposed for sale ... ${ }^{31}$
}

The possibility of an emotional response in favour of the rejection of slavery is here clearly stated along precise racial lines. The abject bodies of Negro slaves with their "woolly heads and black skins" were seen as a deterrent to an abolitionist reading of the sculpture. Instead, the dominantly white viewing audience of Powers' Greek Slave was urged to read the slave body as white or at least inter-racial. It was through the identification of white negros, the "daughters of white men" whose bodies bore the symbolic signs of white female identity - "white skins, fair hair, delicate beauty" - that the anti-slavery message of the Greek Slave was most widely deployed. ${ }^{32}$

A colonial racial terminology deeply invested in an obsessive quantification of race - here blackness - was central to nineteenth-century discourses of the body. The term "octoroon" was used to signify a person who was one-eighth black. The terms "quadroon" and "mulatto" indicated people who were one-quarter and one-half black respectivcly. The fact that a person who was seven-eighths white and only one-eighth black would be rejected from the racial identification of whiteness demonstrates the extent to which blackness was viewed as a pathology which could corrupt the imagined purity of the white body. However, in as much as the body of the octoroon represented an aesthetically acceptable "black" body, it was also a transgressive site since, as Karen Sánchez-Eppler has noted,

The quadroon's one-fourth blackness represents two generations of miscegenating intercourse, the octoroon's three - their numcrical names attesting to society's desire to keep track of ever less visible black ancestry even at the cost of counting the generations of institutionalized sexual exploitation. ${ }^{33}$

The female octoroon and her inter-racial counterparts were popularized as tragic heroines within mid-nineteenth-century American abolitionist fiction. ${ }^{34}$ The octoroon elicited sympathy because for all intents and purposes she was identifiable as white - or at least not readily visible as black. Traces of her Negro ancestry were often detectable in a "ruddy" complexion (effectively disavowed by white marble statuary) or her "too wavy or curly" hair. But her otherwise white physiognomy allowed her to conform to Eurocentric paradigms of beauty and hence western aesthetic norms, while simulcaneously her blackness provided the justification for a more limitless sexual (dis)ordering of the female body. ${ }^{35}$

Unlike Hiram Powers, several nineteenth-century sculptors engaged with the subject of the inter-racial body directly, as opposed to the circumspect route of cloaking the black subject in a white aesthetic acceptability. In 1861 the American sculptor John Rogers Jr. began production on what he envisioned as a career-defining life-size sculpture entitled The Flight of the Octoroon (ca. 1861). ${ }^{36}$ Although never completed, Rogers' immense aspirations for the work were explicitly documented in his desire that his sculpture be "what the Greek Slave was to [Hiram] Powers." 37

While the representation of black subjects would become standard for Rogers, the attempt at a life-size, marble sculpture was indeed ambitious for the artist who had made his name on the sale of mass-marketed, small-scale plasters like his The Slave Auction (1859). As Rogers himself described in a letter to his mother, his choice of this specific inter-racial, black female type enabled representational possibilities which neither a strictly white nor black female subject could have enabled:

It represents a mother with her child in her arms who is just checking her flight to listen for pursuit. It will be very lightly draped which will give me a good opportunity for modcling form and with the great interest which slavery is exciting and the amount of expression and spirit I can put into the figure I feel every confidence in its success. You know an octoroon can have perfectly classical features and the only distinguishing mark will be a very pretty waviness to the hair. ${ }^{38}$

On the eve of the Civil War, Rogers clearly saw an opportunity to capitalize upon the prolific American and indeed international interest in the subjects of slavery. Rogers' choice of an inter-racial female subject allowed him to exploit the physicality, sexuality and expressive qualities of his sculpture in ways which 
were not possible for a strictly white female body. The most obvious implications of racial preference and colonial desire in Rogers' statement was his matter-of-fact revelation that the octoroon subject, despite her blackness, allowed him to create a female body which could be read as the "Beautiful", the only explicit signifier of racial "orherness" - the abject black female body - being her "pretty waviness of hair". However, it is within this knowledge of the inter-racial subject's increasingly (in)visible blackness that the threat of miscegenation re-occurs and the colonial logic of racial identification is betrayed, for as Karen Sánchez-Eppler has argued:

... miscegenation and the children it produces stand as a bodily challenge to conventions of reading the body, thus simultaneously insisting that the body is a sign of identity and undermining the assurance with which that sign can be read. ${ }^{39}$

Another example of white artists' engagement with this theme was the British sculptor John Bell's Octoroon (ca. 1868), a full-scale marble figure of a standing female nude (fig. 4). Exhibited at the Royal Academy, London, in 1868, Bell's whitenegro slave possesses the classical white beauty and "pretty waviness of hair" which John Rogers had intended for his unfinished marble. ${ }^{40}$ But her racial difference is also registered in her large bosom and wide hips, the voluptuous and womanly body which makes Powers' female slave seem comparatively girlish and asexual. ${ }^{41}$ The strong narrative context of Powers' Greek Slave was also not achieved. The identity of the octoroon was unclear, as was that of her enslaver and the nature of her enslavement, and unlike Powers' white female slave, whose fidelity and morality were confirmed by her locket and cross, she was devoid of the symbolic trappings of proper womanhood. Instead, her voluptuous body and the phallic exploitation of her unbound hair simultaneously identified her with and displaced her from the racial paradigm of whiteness.

The (im)possibility of the black female body was such that the figure of the octoroon or inter-racial black woman became almost synonymous with the black woman within nineteenthcentury American neoclassical sculpture. Not so for the black male body. John Quincy Adams Ward's The Freedman (1863) clearly articulated a so-called full-blooded Negro physiognomy registered in the full lips, broad nose and kinky hair of the seated male figure (fig. 5). A striking example of the representational (im)possibilities and differences between the black male and female bodies was created in Edmonia Lewis' Forever Free (1867, fig. 6). The standing male's kinky hair and broad nose are absent from the kneeling woman with classicized facial features and unbound, relatively straight hair. The problems which sculptors faced in signifying race for the black female
Figure 4. John Bell, Octoroon, ca. 1868. Marble, $160 \times 52.5 \mathrm{~cm}$, Blackburn, Blackburn Museum and Art Gallery, Paid for by subscriptions raised by the great and the good of Blackburn (Photo: Victoria and Albert Museum Picture Library).

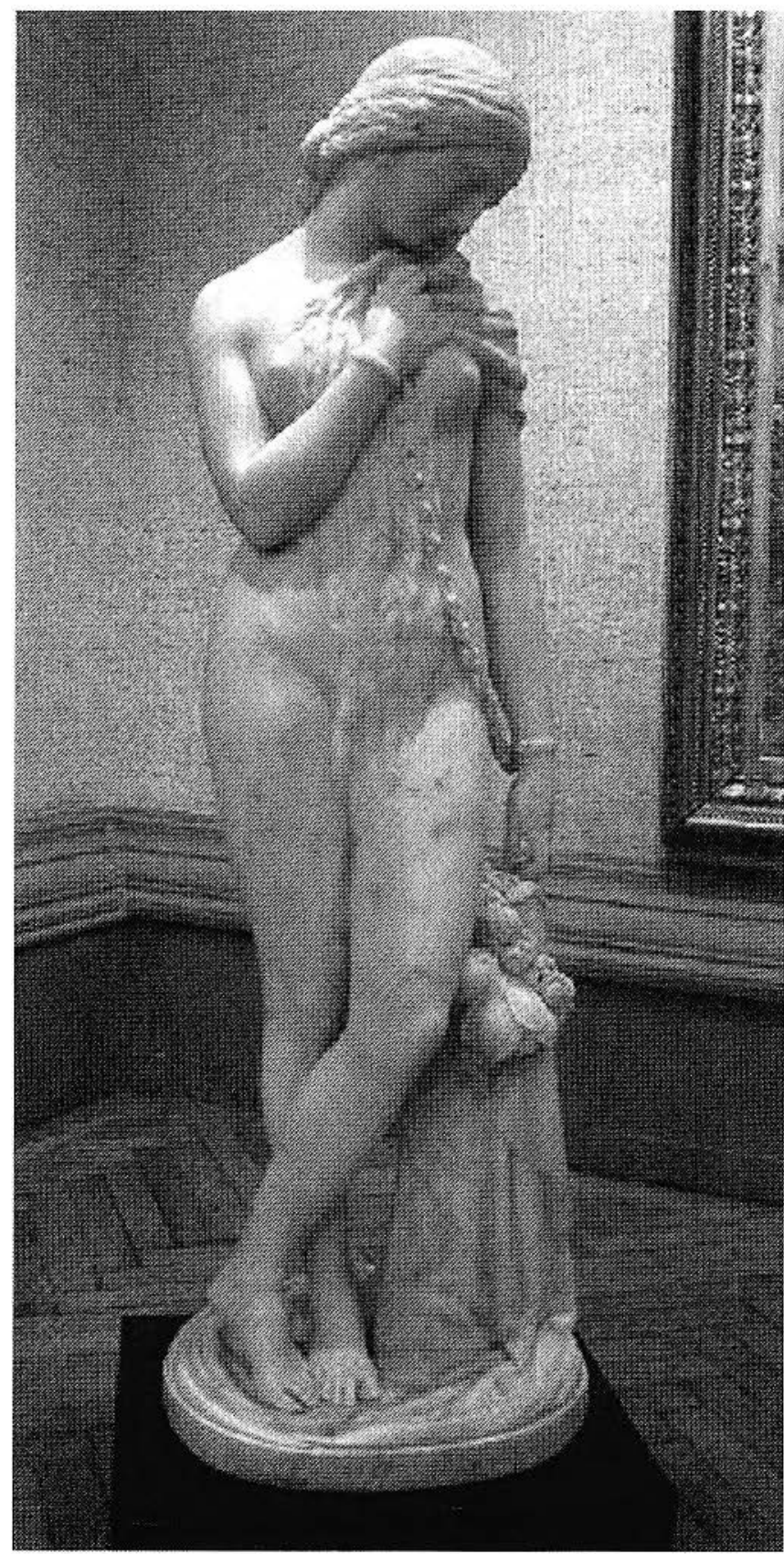

body was explicitly revealed in Anne Whitney's struggles to race the body of her allegorical Africa (ca.1863-64, fig. 7). In an attempt to represent an "appropriate" level of blackness, Whitney re-worked the face of her black female subject several times, receiving criticism from her friend, Thomas Wentworth Higginson, for her avoidance of an explicitly black type. ${ }^{42}$ So, Whitney's Africa was considered by some to be too white. But such criticism was rare within the colonial practice of nineteenth-century neoclassical sculpture. 
Figure 5. John Quincy Adams Ward, The Freedman, 1863. Bronze/metal, height $49.8 \mathrm{~cm}$. Cincinnati, Cincinnati Art Museum, Gift of Alice Keys Hollister and Mary Eva Keys (Photo: Cincinnati Art Museum, Walsh 1999).

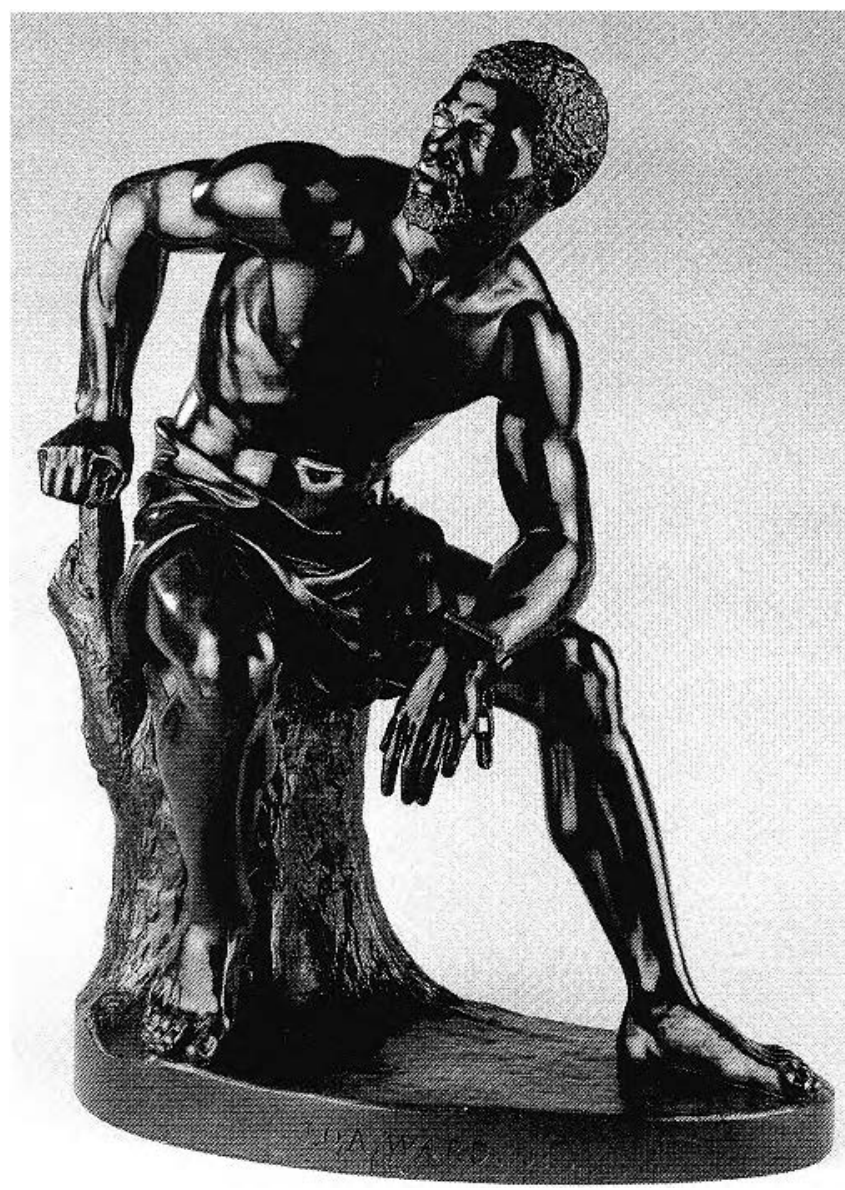

William Wetmore Story's Libyan Sibyl (1861, fig. 8), a companion to his infamous Cleopatra (1861, fig. 9), was intended as an ideal representation of the black female abolitionist orator, Sojourner Truth. Story's sculptural choices register two disavowals. Firstly, at the level of subject, Story's rejection of a portrait in lieu of an allegorical figure begs questions of the ability of the heroic black female subject to be incorporated into neoclassical sculpture. Secondly, Story's statement that he took as his racial model "Libyan African of course, nor Congo" iocates preferable types of blackness - the blackness which was most mixed with or associated through geographical proximity with whiteness - and the rejection of the so-called full-blooded Negro type, here identified explicitly with sub-Saharan Africa. ${ }^{43}$ Story's Cleopatra, displayed at the International Exhibition of 1862 at London, was also exuberantly received as a black queen, her body shifting between identifications of Nubian and Egyptian, allowing for an animalization of her sexuality and the repeated citations of corporeal excess. ${ }^{44}$
Figure 6. Edmonia Lewis, Forever Free, 1867. Marble, Washington, D.C., Howard University Gallery of Art (Photo: Howard University Gallery of Art. Washington D.C.).

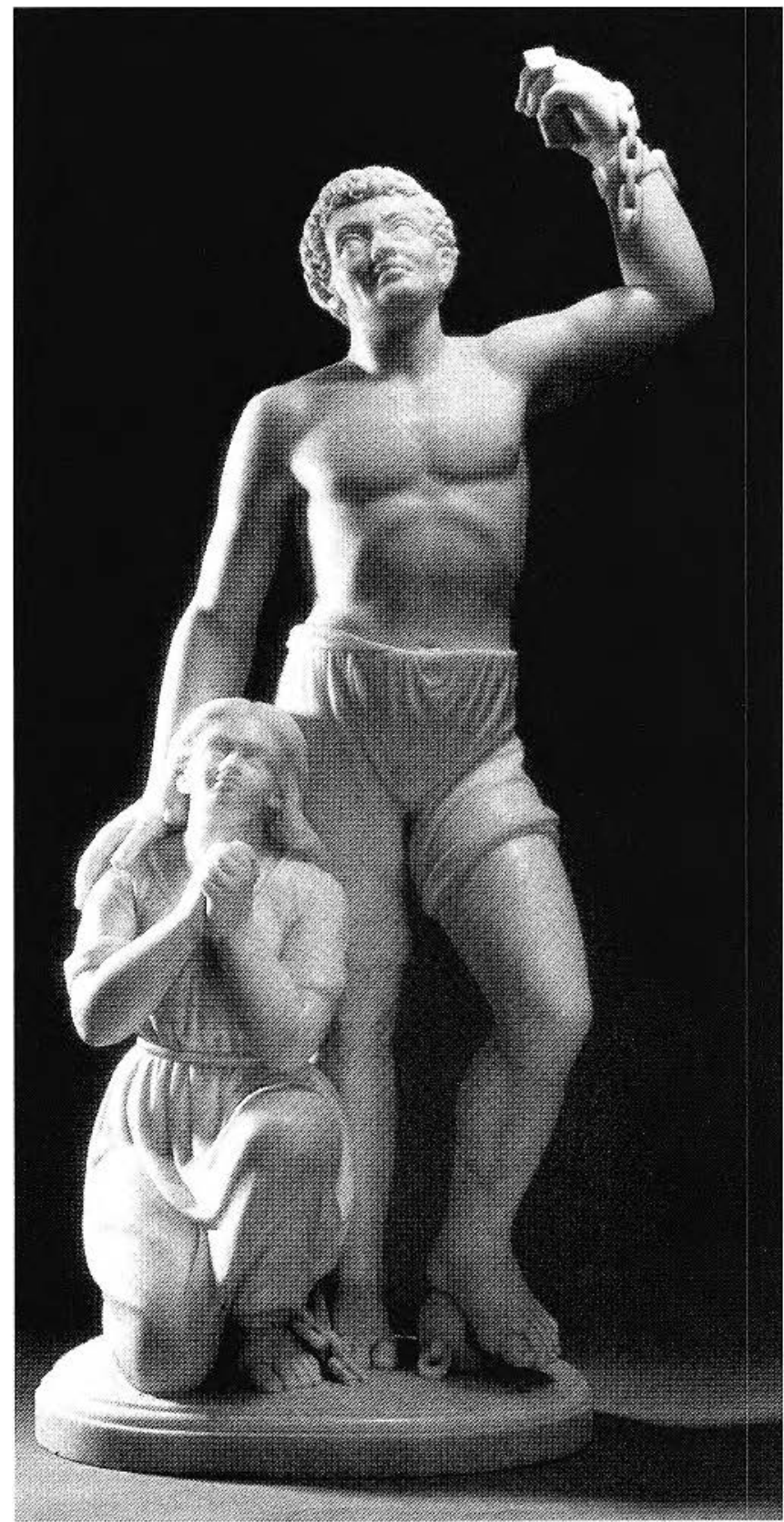

The difficulties artists faced in racing the black female body were largely attached to two main issues determined by the nineteenth-century "scientific" rejection of the black body: beauty and sexuality. As such, when the so-called full-blooded Negro female was allowed to be made visible, the context or theme of the sculpture called for a marginalized or abject female subject. I will close my discussion with an analysis of two very different works which are united in their representation of a legible so- 
Figure 7. Anne Whitney, Africa, ca.1863-64. Marble, original destroyed by artist. (Photo: courtesy of the Wellesley College Archives, Wellesley, MA).

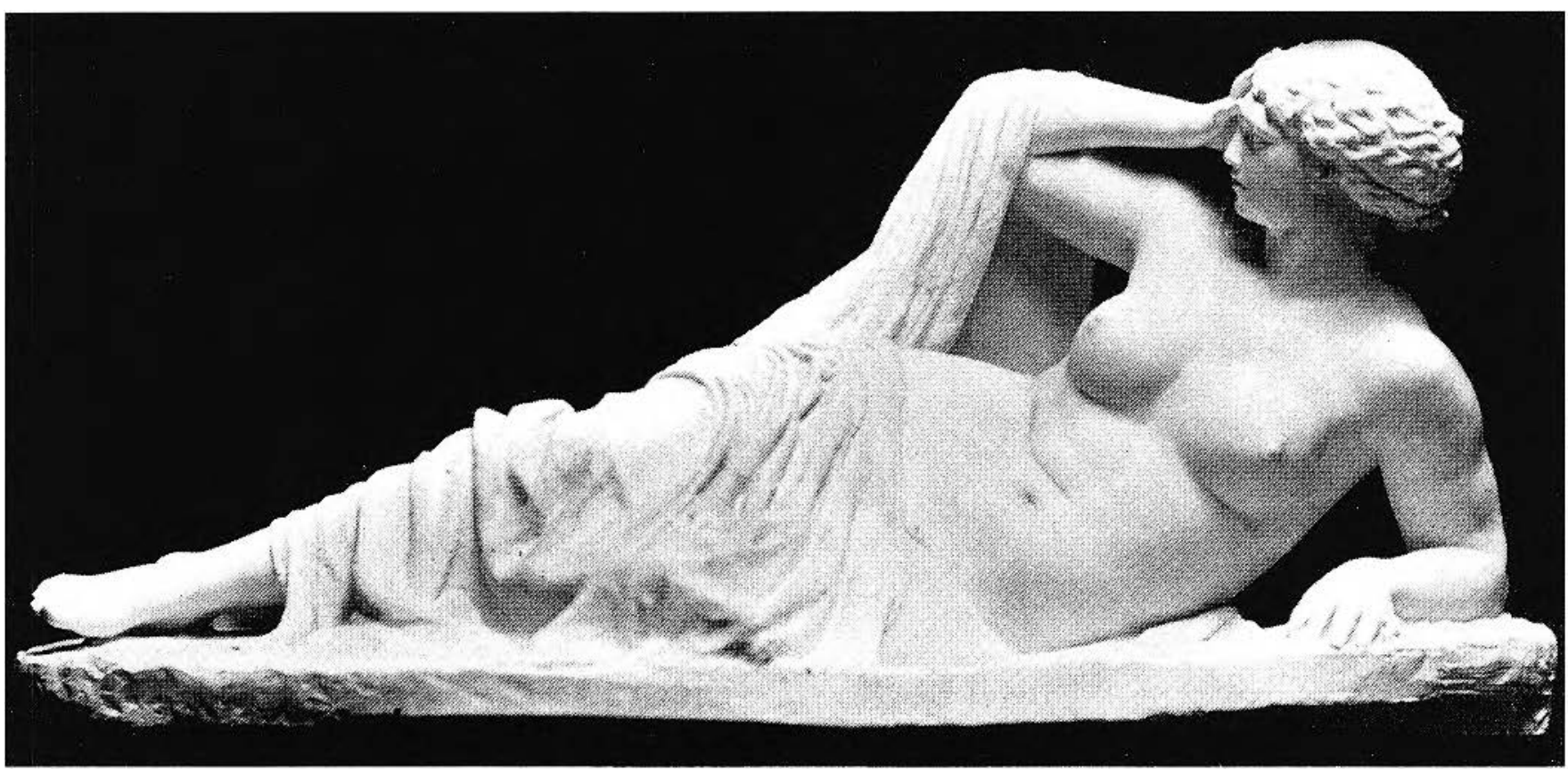

called full-blooded Negro type. While the blackness of the female subject in the first work was facilitated by the more unconventional representational limits of nineteenth-century print media and the diversity of the cross-class audience who consumed it, the second example should draw our attention to the significance of the subjectivity of the artist and the issue of how their national and geographical specificity informs the racial limits of the subjects they represent.

Published in the January-June 1851 edition of Punch, or the London Charivari, John Tenniel's The Virginian Slave: Intended as a Companion to Power's "Greek Slave" (fig. 10) disrupted the white audience's ability to displace their colonial fear/desire of "other" bodies and reconcile a colonial gaze. 45 Tenniel replaced Powers' safely white female slave with a woeful black female slave, stripped to the waist, her lower half covered in a tattered-looking skirt, hair bound in a scarf and hands and feet shackled with more than decorative chains. Beside the slave, the phallic pillar once draped with discarded garments, cross and locket was now wrapped poignantly in the Union flag of the American North (later to become the American flag), the impotent symbol of democracy, while her pedestal is decorated with a succession of whips and chains above the now ironic slogan "e pluribus unum" (from many, one). ${ }^{46}$ In a subsequent edition, Punch imagined "Sambo" (the stereotype of an emasculated black male slave) responding to Powers' white female slave:
But though you am a lubly gal, I say you no correct; You not at all de kind ob slave a nigger would expect; you never di no workee wid such hands and feet as dose; You different from SUSANNAH, dere, - you not like coals black ROSE.

Dere's not a mark dat I see ob de cow-hide on your back; No slave hab skin so smooth as yourn - dat is, if slavee black. ${ }^{47}$

Hence, the poignancy and for some the "humour" of Punch's ever so Negro Virginian Slave resided in the painful clarity of her racial difference from the comparatively delicate, leisured and asexual body of Powers' white female slave. As the poet recognized, the body of the white female slave did not bear signs of slavery. It was not muscled from physical labour; it had not been branded by an "owner"; it did not bear the violent marks of the whip. Rather, as Kirk Savage has noted, the white female slave body still retained her religious, racial and class identifications and had not undergone the "social death", the (de)/(re)-identification of the slave body of which Orlando Patterson has written. ${ }^{48}$ In comparison, the black female slave was quite simply beyond the symbolic order, outside the limits of what was representable within the canons of western so-called "high art" practice. The black female slave of America and the diaspora was the (im)possible subject, the (no)body of neoclassical sculpture, or at least, sculpture 
Figure 8. William Wetmore Story, Libyan Sibyl, 1861. Marble, $134.6 \times 109.5 \mathrm{~cm}$. New York City, The Metropolitan Museum of Art, Gift of the Enving Wolf Foundation (Photo: The Metropolitan Museum of Art, N.Y.).

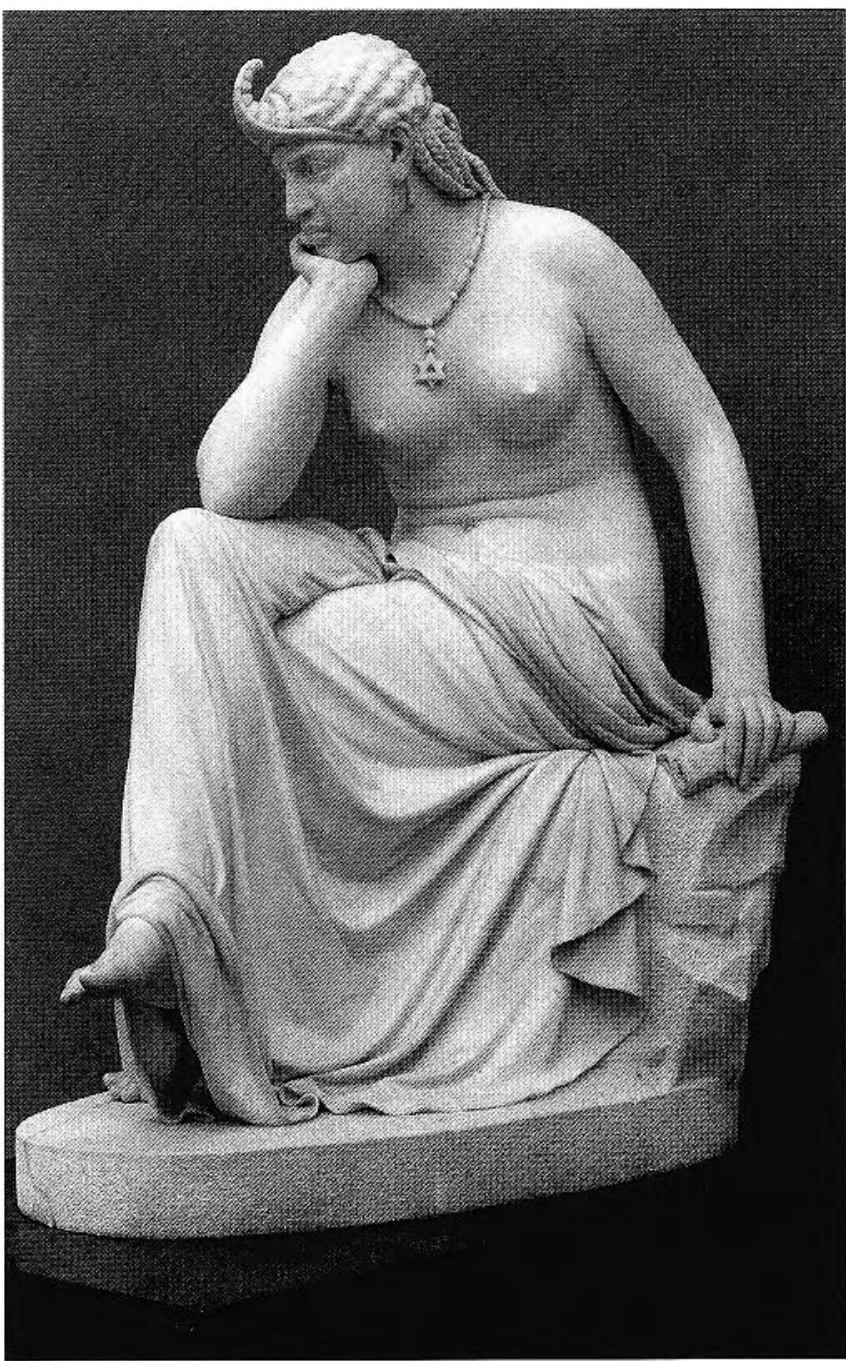

whose intention was to rally moral indignation or symbolize Beauty.

It was however possible to deploy the body of the black female slave to other uses - mainly the abject racial body via social/economic disenfranchisement, noted above, or titillation and sexual spectacle. The Italian sculptor Giacomo Ginotti's L'emancipazione dalla schiavitu (1877) exemplified this latter potential (fig. 11). The pose, composition, expression, context and narrative of this obviously black female slave stood in immediate contrast to the works by his American contemporaries. Ginotti clearly identified a so-called full-blooded Negro type by signifying deeply curled hair which escaped from the head scarf and identifiably black facial features. Like Bell's Octoroon, Ginotri's slave is largely devoid of the elaborate narrative context which facilitated and legitimized the nudity of
Figure 9. William Wetmore Story, Cleopatra, 1869. Marble, height $138.4 \mathrm{~cm}$. New York City, The Metropolitan Museum of Art, Gift of John Taylor Johnston (Photo: The Metropolitan Museum of Art, N.Y.).

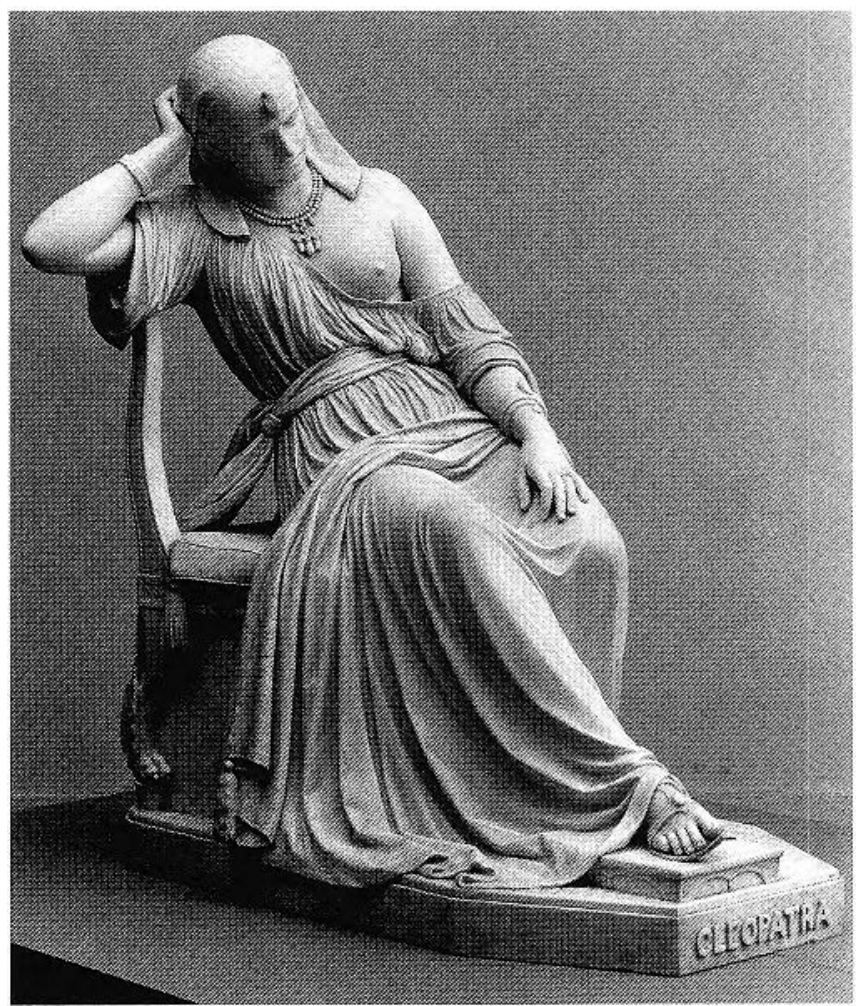

white female subjects like Powers' Greek Slave. The black female body, defined by large globular breasts and full hips and buttocks, anatomically surpassed the voluptuousness and, therefore, sexual readiness even of Bell's Octoroon. The ironically shackled wrists of Ginotri's "emancipated" slave provided an excuse to represent her sexualized writhing and ministrations which provoke an eroticized and illicit pose wherein her breasts are forced together and upwards, accentuated rather than concealed by the pendant cross, which falls across her chest grazing her nipple, and the string of jewels wrapped about her upper left arm which is juxtaposed with the left breast. ${ }^{49}$ The orgiastic movements of the black slave's body also locate action, resistance and passion, all attributes which were oppositional to the patriarchal ordering of the white female body. As one male reviewer commented, "... the blood rebels in her veins." 50 In lieu of the desire which supposedly chaste white marble nudes could engender in nineteenth-century viewers, it is not surprising that Ginotti's black female slave also provoked inappropriate sexual feelings in its viewers - feelings associated with the pornographic. The same male author wrote of his desire that "... the marble was a live woman," 51 presumably so that he could engage in some sort of sexual interaction with her.

Nineteenth-century neoclassical sculpture was deeply invested in the racial differencing of the body. Neoclassicism's 
Figure 10. John Tenniel, The Virginian Slave: Intended as a Companion to Power's "Greek Slave", 1851. Engraving, Manchester, The John Rylands University Library of Manchester (Photo: courtesy of The John Rylands Library of Manchester, Manchester, UK).

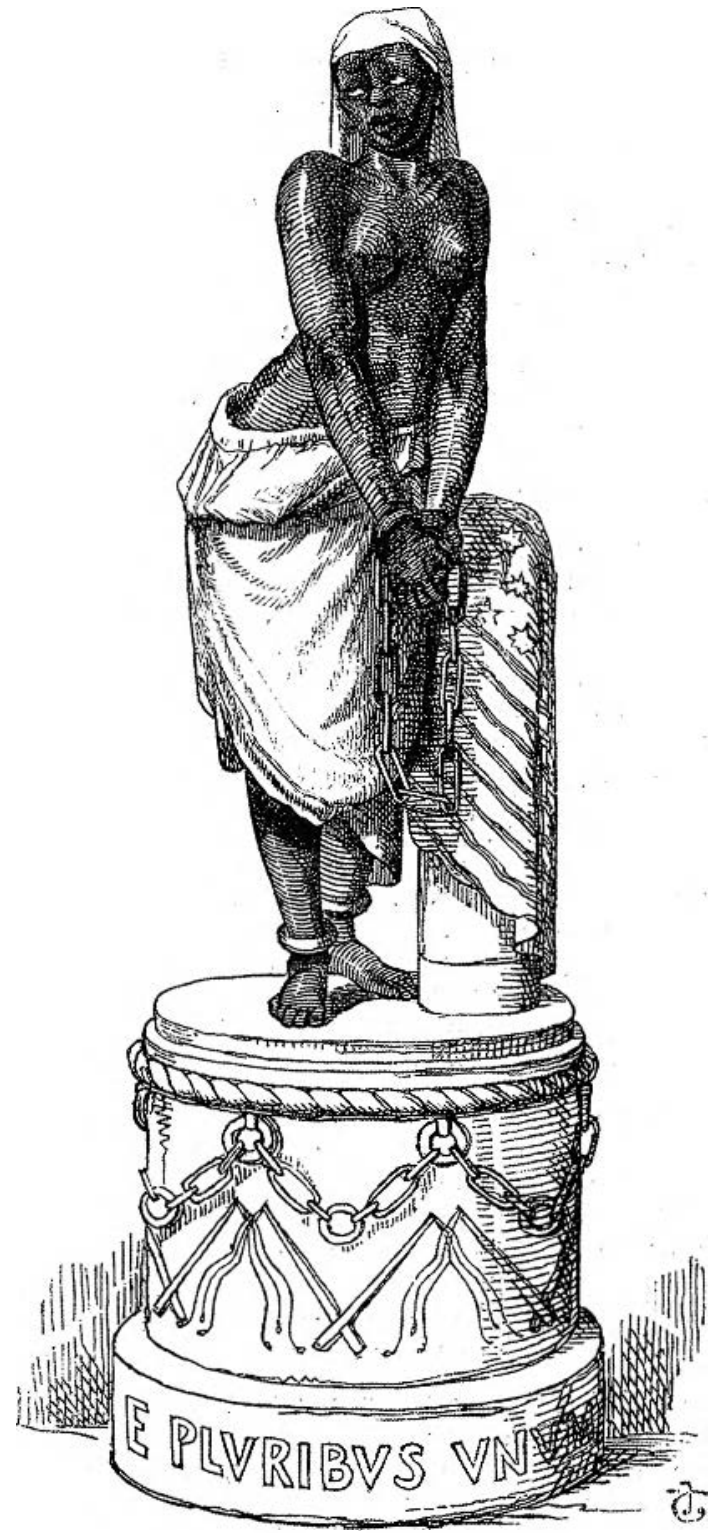

THE VIRGINIAN SLAVE.

INTENDED AS A COMPANION TO POWER'S "GREEK SLAVE."

fealty to white marble points up a disavowal of the black subject which was also actively enforced through limits of subjectivity. Within a colonial order, a black female subject, represented outside of the simultaneous marginalizations of race and sex, was a threat to the racial privilege of the white body and may not have been legible at all. Instead, the dominance of the interracial female body, a liminal site which simultaneously placated white anxiety and thwarted white denial of miscegenation,
Figure II. Giacomo Ginotti, L'emancipazione dalla schiavitu, 1877. Marble, height $155 \mathrm{~cm}$. Naples, Museo e Gallerie Nazionali di Capodimonte (Photo: Soprintendenza per il Patrimonio Artistico Storico di Napoli).

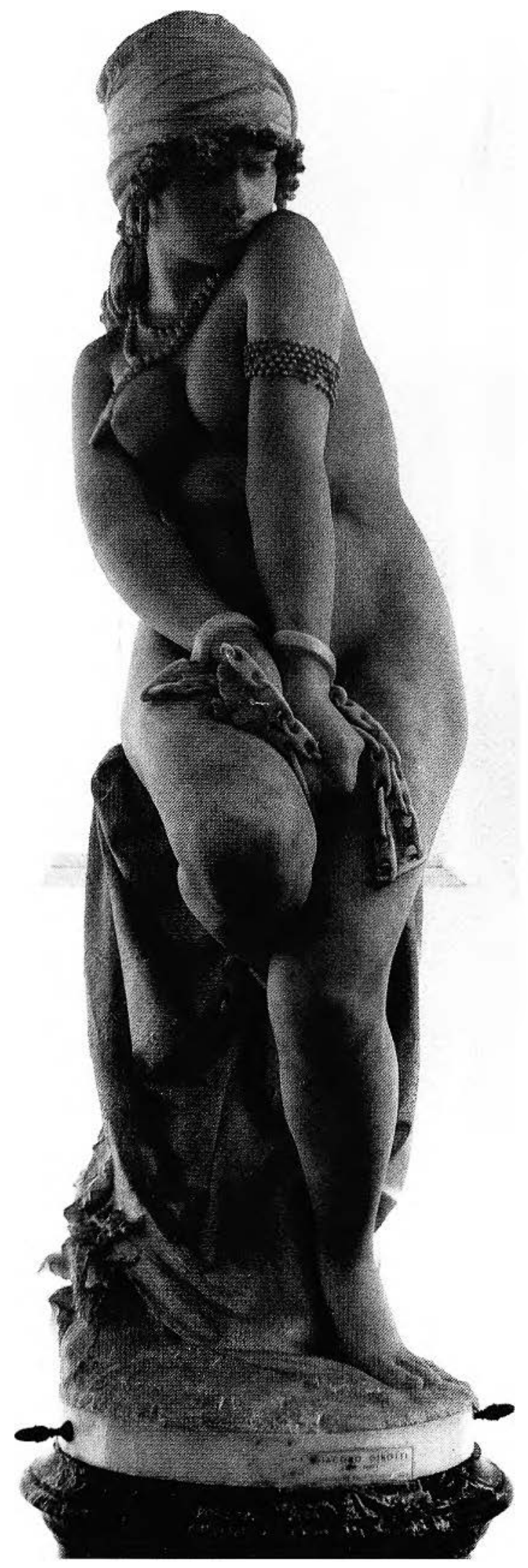


should alert us to the deep ambivalence of racial identifications, since, of course, this white-negro body was not possible at all without the inter-racial contact and violence that the white mind most feared and denied.

\section{Notes}

1 Albert Gardner, Yankee Stone Cutters: The First American School of Sculpture (New York, 1945), 21. Jean Fagan Yellin has detailed the symbolic significance of chains to the representation of the enslaved subject within nineteenth-century abolitionist discourse. The deployment of chains, manacles or shackles, like the liberty cap, became so indelibly linked to abolitionist visual discourse that pro-slavery advocates aggressively sought to curtail their use in national art commissions. See Jean Fagan Yellin "Caps and Chains: Hiram Powers' Statue of 'Liberty'," American Quarterly, 38 (1986), 798-826.

2 It is crucial to note the extent to which, within nineteenth-century discourses of race, being black was often commensurate to being a slave. In his Democracy in America (1835), Alexis de Tocqueville described blackness as "the eternal mark of ignominy" which Negroes could not help but transmit to their descendants. This biological essentialism located blackness as the source of inherent racial inferiority. Blackness then was a symbolic mark of race which determined social status and potential yet was also significantly divorced from both, since Tocqueville did not distinguish between free or enslaved blacks. To be free as a black, then, was to be free of the "eternal mark" and thus not to be black at all. See Alexis de Tocqueville, Democracy in America, tr. Henry Reeve (1835; repr. London, 1900).

3 During the nineteenth century, slavery was commonly referred to in America as the "peculiar institution", a term which captured the inherent contradictions of many of its structures and practices and the ambivalence of its racialized subjects. Charmaine A. Nelson, "Narrating Blackness: Studies in Femininity, Sexuality and Race in European and American Art of the Nineteenth-Century," Ph.D. diss., University of Manchester, 2001, 161, 163, 199.

4 Elizabeth Grosz has argued that time, as a commonly assumed term of all discourse, has nevertheless suffered great scholarly neglect as a primary focus of research. The idea of bodily becoming or materialization is evident in various branches of critical academic and theoretical scholarship which has contested the concept of identity as a fixed and static notion relatable to a body with definitive attributes and meanings. Judith Butler's notion of morphology is particularly useful to the idea of becoming since it describes the body's materialization as an ability to produce a morphe or image of the body/self. The key to these notions is that identity is active and ongoing. Such a conceptualization of the body has an obvious potential to disrupt the production and deployment of colonial and other stereotypes which have functioned through the assumption of the fixity and always already-ness of identity. Psychoanalysis is also useful to the theoretical revisioning of the body precisely since its historical phallocentrism and coloni- alism demonstrate the negotiation of identity and identification as a process of materialization based upon the interaction of subjects and their differentiation according to a normative body. Elizabeth Grosz, ed., Becomings: Explorations in Time, Memory, and Futures (Ithaca, 1999).

5 Judith Butler, Bodies That Matter: On the Discursive Limits of Sex (New York, 1993), 76.

6 Butler, Bodies That Matter, 65.

7 While on a specific level I am referring to an examination of identity and identification within the nineteenth-century practice of neoclassical sculpture and western visual art, I am also referring to a larger theorization of identity as a process of constant negotiation. See Stuart Hall, "Introduction: Who Needs 'Identity'?," Questions of Cultural Identity (London, 1996).

8 Butler, Bodies That Matter, 65.

9 Joy S. Kasson, Marble Queens and Captives: Women in NineteenthCentury American Sculpture (New Haven, 1990), 32. The moral and religious purpose of art was widely accepted and is reflected in Nathaniel Hawthorne's concept of sculpture as "sermons in stones". Nathaniel Hawthorne, The Marble Faun: or the Romance of Monte Beni (1860; Rpt Cincinnati, 1968), 151.

10 Kirk Savage has noted the relationship between sculpture and the "theoretical foundations of racism". Kirk Savage, Standing Soldiers, Kneeling Slaves: Race, War, and Monument in Nineteenth-Century America (Princeton, 1997), 8.

11 Edward E. Hale, Ninety Days' Worth of Europe (Boston, 1861), 150.

12 For a discussion of fetishization as the regulation of difference, see Parveen Adams, The Emptiness of the Image: Psychoanalysis and Sexual Differences (London, 1996), 32.

13 Wolfgang Drost, "Colour, Sculpture, Mimesis: A Nineteenth-Century Debate," in The Colour of Sculpture: 1840-1910, ed. Andreas Blühm (Amsterdam, 1996), 62.

14 I have found no references to imply or confirm that artists used wash, pigment or chemicals to bleach the marble a more "pure" white colour.

15 Whereas applied polychromy can be defined as sculptures constructed of white marble to which pigment was later added, frequently through tinting or painting, material polychromy indicates the use of more than one type and colour of material in a sculpture (ie. bronze and multiple colours of marble).

16 Anne Brewster, "American Artists in Rome," Lippincott's Magazine of Literature, Science, and Education, 3 (February 1869), 197.

17 The coloured pavilion was a large architectural enclosure designed to house and exhibit the sculpture. Classical in style, the pavilion was also painted or polychromed to coincide with Gibson's own work.

18 The American sculptor Joseph Mozier was also known to dabble in polychromy. In at least one version of his Wept of Wish-ton-Wish (1859) he adopted the controversial practice, presumably to emphasize the blonde hair and blue eyes of the female subject described in James Fenimore Cooper's book of the same name published in 1829. A version of this work is in the collection of the Hirschl and Adler Galleries, New York. Kasson, Marble Queens and Captives, 97. 
19 "Notabilia of the International Exhibition," The Art Journal (July 1862), 161.

20 T.Q. (a.k.a. Samuel Young Jr.), A Wall-Street Bear in Europe, With his Familiar Foreign Journal of a Tour Through Portions of England, Scotland, France and Italy (New York, 1855), 57, 98.

21 These concepts, first popularized in art historical discourse by Kenneth Clark, have been subsequently developed with social art historical and feminist perspectives. While Kenneth Clark associated the nude with art and beauty, he characterized the naked as a shameful and embarrassed state of undress which corresponded with the category of pornography and the Kantian notion of the sublime. Subsequently, T.J. Clark addressed the nude and the naked in terms of class identifications in his discussion of the representation of the bodies of prostitutes in nineteenth-century French painting. Feminist art historians have expanded the categories to describe the representational possibilities and limitations of the female body within a traditionally patriarchal visual culture. Using psychoanalysis, Lynda Nead has aptly noted the gender/sex specificity of these concepts. She has discussed the nude as the controlled and ordered female body, the body disciplined (ferishized) by the artist to disguise the sexual lack of female otherness and present a legible and palatable (phallicized) female body for a dominantly heterosexual male gaze. In contrast she has located the traditionally transgressive potential of the naked in its dis-order, its biological and social specificity and the way it points up the process of becoming the nude, often through the representation of clothing which disrupts the idea of an always already unclothed body. However, these art historians have largely overlooked the extent to which both concepts have been informed by race and defined according to the paradigm of the white female body and therefore offer racially and sexually exclusive definitions of the sexualized body. In my assessment of the racial specificity of the representation of the black female body as the nude or the naked, I have determined that attributes of both categories often co-existed simultaneously since the representation of the black female subject was often strategically deployed outside of the sexual limits of white bourgeois female identity. See Kenneth Clark, The Nude: A Study in Ideal Form (New York, 1957); T. J. Clark, The Painting of Modern Life: Paris in the Art of Manet and his Followers (London, 1985); Lynda Nead, The Female Nude: Art, Obscenity and Sexuality (London, 1991); Charmaine Nelson, "'Coloured Nude': Fetishization, Disguise, Dichotomy," RACAR: Revue d'art canadienne/Canadian Art Review, XXII, nos. 1-2 (1995), 97-107.

22 Hale, Ninety Days Worth of Europe, 149.

23 Hale, Ninety Days Worth of Europe, 149.

24 James Jackson Jarves, Art-Hints, Architecture, Sculpture and Painting (London, 1855). Jarves distinguished between "high art" and "common art"; the former being products of genius which included works of the spirit which appealed to the soul and the latter "faithful representations of natural objects" which were a product of "industry and clever imitation".

25 Jarves, Art-Hints, 66, 155-56. There exist classical examples of sculptural busts which indicate a seemingly arbitrary relationship between the race of the subject and the colour of stone or other material used to represent their skin colour. Several portrait busts in the collection of the Musei Capitolini (Piazza del Campidoglio, Rome) are indicative of this tendency. In some cases non-white stone or other material was used to represent the flesh of white subjects. However, my research indicates that nineteenth-century polychrome sculptures generally utilized coloured materials best suited to represent the skin colour and race of the subject in question. Even when white subjects were sculpted using polychromy techniques, their flesh was created with a type and colour of material which represented its whiteness.

26 In English, this sculpture is often identified as Sudanese in Algerian Dress.

27. For an innovative discussion of castration as fetish, an attempt to disavow female sexual difference instead of the Freudian definition of the fetish as a tool for disguising female sexual lack, see Charles Bernheimer, "Castration' as Ferish," Paragraph, 14 (1991), 1-9, esp. 3.

28 The first version, originally intended for Lord Powerscourt, was instead ordered in 1843 by Captain John Grant of Devonshire, England, completed in 1844 and is now in a private collection and housed at Raby Castle, Staindrop, Durham, England. Powerscourt, who presumably quibbled with Powers about the price, later regretted "losing" the work to another patron. The second version, commissioned in 1846 and intended for Lord Ward (later the Earl of Dudley), instead entered the collection of James Robb of New Orleans after public exhibition in America. After being exhibited by Robb in New Orleans, the sculpture was sold to the Western Art Union of Cincinnati which raffled the work in a lottery won by William Wilson Corcoran. This version is today in the Corcoran Gallery of Arr, Washington, D.C. The third version, from 1847 , was extensively exhibited throughout America after being declined by the original patron, Sir Charles Coote of Dublin, due to "change of fortune". The sculpture was then purchased by C. L. Derby of Sandusky, Ohio, in 1854 before being awarded in a lottery through the Cosmopolitan Art Association to Mrs. Kate Gillespie of Brady's Bend, Pennsylvania, in 1855. Mrs. Gillespie exhibited her sculpture in Ohio and Pennsylvania before it was auctioned in New York in 1857 and re-acquired by the Cosmopolitan Art Association for $\$ 6000$. After exhibiting the sculpture at the Dusseldorf Gallery in New York, the Association again offered it in a lottery on 5 June 1858 when it became the property of Miss Coleman of Cincinnati who sold it to the collector Alexander T. Stewart. After Stewart's death, the work, sold through the American Art Association, was acquired by Captain Delmar for a mere $\$ 1250$, eventually ending up in the collection of Franklin Murphy whose son gifted it to the Newark Museum in 1926. The fourth version, destined for Lord Ward (Earl of Dudley), is today unlocated. The fifth version, which was purchased by the Russian Prince Paul Demidoff for his villa San Donato near Florence for 700 pounds, was later owned by a string of collectors including Mr. Phillips, Edward M. Scott of London, Claude de Bernales, Alton Lodge, Roehampton, and Michael Harvard, London, before being purchased from the New York market by Yale University Art Gallery in 1963. And finally the sixth version, from 1869, was commis- 
sioned by E. W. Stoughton of New York and donated to the Brooklyn Museum by his heirs. Regarding the first version, see C.E. Lester, The Artist, the Merchant and the Statesman of the Medici, and of our Own Times, 2 vols. (New York, 1845), I, 84-85; regarding all versions, see Samuel Roberson and William H. Gerdrs, "“... so undressed, yet so refined ...': The Greek Slave," The Museum: New Series, 17, nos. 1-2 (Winter-Spring 1965), 3-23.

29 Part of a sculpture's quality was judged by the artist's ability to narrate a safe space of viewing and to aestheticize and abstract the human body in a way which permitted the viewer to consume unclorhed subjects within nineteenth-century bourgeois limits of politeness and sexual propriety. Neoclassical subjects, frequently unclothed or partially draped, were often female. Their nudity needed to be justified with a cause which would remove responsibility for a potentially transgressive sexual gaze from the white female subject. The expectation of polite nudity was complicated by slavery whose brutalities, regularly represented within popular culcure, were deemed largely inappropriate for the realm of "high art". Powers himself was instrumental in the fabrication of a moral tone for his Greek Slave. In a letter to a patron, he detailed his desire to sculpt a Christian slave whose piety and chastity, in the midst of grave moral and sexual menace, made her unaware of her nakedness. This moralizing narrative was to be continually repeated in newspaper reviews, laudatory poems and descriptions of the sculpture. Letter, Hiram Powers to Edwin Stoughton, 29 November 1869, Hiram Powers Papers, Archives of American Art, Smithsonian Institution, Washington, D.C.

30 The political ambivalence of Powers' Greek Slave is evident in its celebration by pro-slavery factions. The popularity of the sculpture was proved in the success of public tours and the fact that one of the sculpture's earliest patrons was a slaveholder from South Carolina, the state which held the dubious honour of having the most slaves in the Union in 1860. David Moltke-Hanson, Art in the Lives of South Carolinians: Nineteenth-Century Chapters (Charleston, 1979), RSa7, Rsb5-7.

31 Christian Inquirer, vol. 1 (9 October 1847), 207, Hiram Powers Scrapbook; cited in Vivien Green, "Hiram Powers' Greek Slave: Emblem of Freedom," American Art Journal, 14, no. 4 (Autumn 1982), 38; and partially cited in Savage, Standing Soldiers, Kneeling Slaves, 28. This quote explicitly locates the conflation of race and class positions since it is the "whiteness" of these "daughters of white men" which has informed their expectations of "fortune". But it also indexes the white male privilege of patriarchy since it is the white fathers who have the social, political and legal privilege to own the property and create the wealth which their "black" daughters were denied.

32 Within the practices of trans-Atlantic Slavery, any child born to a black female slave was historically deemed to be a slave also. Significantly then, the Christian Inquirer's emphasis on the paternal lineage of the female slaves, "daughters of white men", served to locate the status of inter-racial children within colonial legal discourses. The existence of white fathers of black slaves named the entrenched practices of sexual violation which saw black women raped by white men for the purpose of the economic expansion of property: the conception of new slave bodies/commodities. But the author's refusal to name the "other" sexual possibility of interracial children - white mothers and black fathers - also spoke volumes about the absolute denial of the possibility of sexual attraction/contact between these two subjects, a refusal supported by the stereotypes of the chaste, virginal and pure white female and the animalized, lascivious black male rapist. This stereotype, which was used to justify the practice of lynching, mirrors the racial stereotypes deployed against Turkish men in the narration of Powers' Greek Slave. See Camille Nelson, Property Law as Oxymora: Female Slaves as "Breeders" of Property, unpublished paper (forthcoming).

33 Karen Sánchez-Eppler, "Bodily Bonds: The Intersecting Rhetorics of Feminism and Abolition," Representations, 24 (Fall 1988), 40.

34 Vivien Green provides a concise list of some of the literary works which adopted the female octoroon as heroine. See Green, "Hiram Powers' Greek Slave," 36.

35 I would argue that part of the fetishization of the black female body has been its disordering, a representational strategy which unlike the representation of the white female body as the nude, did not ultimately seek the containment or control of the body but oppositionally the signification of sexual and corporeal excess. Colonial associations between blackness and excessive, pathological sexuality informed the representation of the black female body in ways which did not conform to the proprietary restrictions of the visualization of the bourgeois white female subject.

36 David H. Wallace, John Rogers: The People's Sculptor (Middleton, CT, 1967), 200. Besides the obvious affinity of nineteenth-century American sculpture for themes which deployed black female subjects and the popularity of "tragic octoroon" narratives, Wallace has suggested that Rogers drew inspiration specifically from Harriet Beecher Stowe's Uncle Tom's Cabin: A Tale of Life Among the Lowly (London, 1852) and Don Boucicault's popular play The Octoroon which was contemporaneously showing in New York where Rogers had his studio. The Octoroon was first performed at the Winter Garden Theatre, New York on 5 December 1859.

37 Wallace, John Rogers, 61, 200. By 1861, Rogers would have been well aware of the iconic status of Hiram Powers' Greek Slave which he saw exhibited at the Boston Horticultural Hall in 1848.

38 Wallace, John Rogers, 200.

39 Sánchez-Eppler, "Bodily Bonds," 41.

40 Bell's Octoroon was also exhibited in Blackburn, England, in the Art and Industry Exhibition (1874) at the newly opened library and museum where it was subsequently, due to the public urgings of a resident named Mr. Jessie Slater, acquired by public subscription, for the reduced sum of 150 pounds from the artist due to defects in the marble. Curatorial Files, Blackburn Museum and Art Galleries, Blackburn, UK, John Bell Octoroon.

41 Such signs of "womanhood" were also read within the context of slavery as signs of female procreative capacity (breeding hips, lactating breasts) and female sexual readiness, discerned in the bodies of black female slaves scrutinized by the white audiences of potential slave-holders who desired physical evidence of the slave's potential to breed and therefore expand the master's economic holdings by both becoming and producing commodities. 
42 Elizabeth Rogers Payne, "Anne Whitney: Art and Social Justice," Massachusetts Review, 12 (Spring 1971), 245-60; cited in Savage, Standing Soldiers, Kneeling Slaves, 59, 228.

43 Jan M. Seidler, "A Critical Reappraisal of the Career of William Wetmore Story (1818-1895), American Sculptor and Man of Letters," Ph.D. diss., Boston University, 1985, 502-22; cited in Savage, Standing Soldiers, Kneeling Slaves, 59.

44 For more on the reception of Story's Cleopatra as a black queen, see Henry Adams, The Letters of Henry Adams: 1858-1868, vol. 1, eds. J.C. Levenson, Ernest Samuels, Charles Vandersee and Viola Hopkins Winner (Cambridge, Mass., 1982), 147; "William W. Story and his Cleopatra," Dwight's Journal of Music, 17, no. 18 (28 July 1860), unpaginated; Hale, Ninety Day's Worth, 145-46; "International Exhibition," The Athenaeum: Journal of English and Foreign Literature, Science, and the Fine Arts, no. 1802 (10 May 1862), 631; Lilian M.C. Randall, "An American Abroad: Visits to Sculptors' Studios in the 1860's," The Journal of the Walters Art Gallery, 33-34 (1970-71), 48; James Jackson Jarves, Art Thoughts (New York, 1879), 312; "Art Notes," New York Times (13 June 1882), C. 2, 2; William W. Story, "Cleopatra," Dwight's Journal of Music, 25, no. 13 (16 September 1865), unpaginated.

45 "The Virginian Slave: Intended as a Companion to Powers' 'Greek Slave'," Punch, or the London Charivari, 20 ( January-June 1851), 236.

46 The Latin expression e pluribus unum, meaning "from many, one" today appears on the Great Seal of the United States and on all coins. The expression was officially adopted on 20 June 1782 by a committee chosen on 4 July 1776 to prepare a device for the nation's seal. Grolier Multimedia Encyclopaedia (Danbury, CT, 1998). Tenniel's clever inclusion of whips and chains on the pedestal recalled the popular allegorical emblem of William Lloyd Garrison's American Anti-Slavery Society in which a female figure of Liberty stands upon broken whips and chains as she holds a banner with a liberty cap atop of its pole.

47 As a colonial stereotype, the "Sambo" was used in the North
American context to emasculate black men by deploying a representation of a "yes mam/sir" subject, a buffoonish character who willingly did the biddings of his white masters and did not contest his inferior racial position. There have been stereotypical equivalents to the "Sambo" deployed in other geographical and national contexts. "Sambo to the 'Greek Slave'," Punch, or the London Charivari, 21 (July-December 1851), 105.

48 Savage, Standing Soldiers, Kneeling Slaves, 30; Orlando Patterson, Slavery and Social Death: A Comparative Study (Cambridge, 1982), 35-76. The Greek Slave's retention of her identifications was due not only to the signification of her body but also to Powers' use of external symbols like the cross and locket which decorate the pillar.

49 Although I have argued that the material practices and aesthetic preferences of nineteenth-cencury neoclassicism erased the efficacy of skin colour as a racial signifier on the material level, within the realm of imagination and fantasy, viewers were able and expected to facilitate and overcome this aesthetic and colour deficit with their own knowledge of the subject and its narrative. Hence, Ginotti's obviously black female slave, though deployed in white marble, allowed for the evocation of the black skin which could not be represented, the black skin which Costantino Abbatecola undoubtedly imagined when he wished this slave woman was alive (see note 50). The blackness which the audience was able to imagine takes on deeper aesthetic meanings when one can also imagine the dramatic juxtapositioning of the brown colour of the slave's breast with the likely white pearls of her upper left arm and colourful beads of her necklace.

50 Costantino Abbatecola, Guida e critica della grande esposizione nazionale di Belle Arti di Napoli del 1877 (Naples, 1877), 104; cited in Hugh Honour, The Image of the Black in Western Art: $N$ From the American Revolution to World War I- 2 Black Models and White Myths (Cambridge, 1989), 171.

51 Abbatecola, Guida e critica, 104; cited in Honour, The Image of the Black, 171. 